\title{
O języku karaimskim i jego dziejach
}

\section{W poprzednim numerze przedstawiliśmy miejsce, jakie język naszych przodków zajmuje wśród języków świata i jego podział na dialekty. W drugiej części rozważań mowa jest o etapach jego rozwoju oraz o alfabetach, jakimi zapisywano go niegdyś i obecnie.}

Pierwsza karta rękopiśmiennego przekładu Księgi Rodzaju na dialekt południowozachodni. Kopista Józef Mordkowicz (1802-1884). Halicz, XIX w.

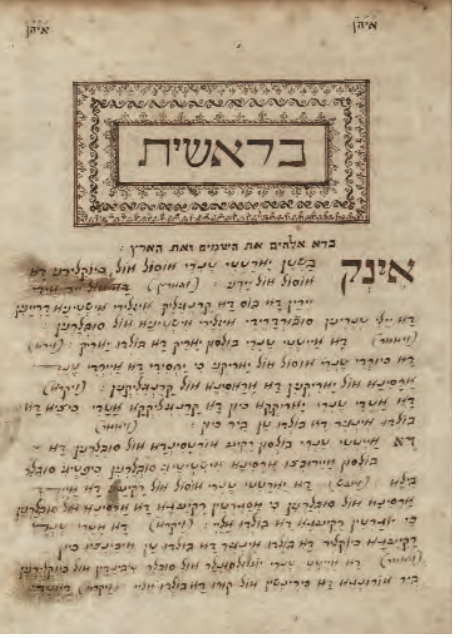

20 Awazymyz Wrzesień 2015
- okres nowozachodniokaraimski (ang. New albo: Modern Western Karaim) trwajacy do dnia dzisiejszego.

Okres starokaraimski trwał do momentu wydzielenia się pierwszej fali migracyjnej Karaimów $z$ terenów wspólnej kohabitacji. Jeśli chodzi o daty założenia najstarszych gmin karaimskich, to wciąż pozostaje wiele znaków zapytania. Zgodnie $z$ tradycją gmina halicka miała powstać około roku $1246^{1}$, jest to jednak teza trudna do dowiedzenia w świetle źródeł historycznych. Tradycja mówi również, że Karaimów na Litwę sprowadził książę Witold w latach 90. XIV w. (na to znajdziemy pośrednie dowody). Wedle świadectwa źródeł historycznych Karaimi osiedlili się na Litwie najprawdopodobniej pod koniec XIV w. ${ }^{2}$, zaś pierwszy wiarygodny dokument poświadczajacy obecność Karaimów w Haliczu pochodzi z roku $1578^{3}$. Natomiast gmina w Łucku $z$ całą pewnościa musiała powstać wcześniej niż halicka, już pod koniec XV w., gdyż w dokumencie z 1506 roku Karaimi są wymienieni jako mieszkańcy Łucka majacy własna świątynię ś $^{4}$

Określenie, kiedy dokładnie nastapił początek tego okresu (a więc kiedy powstał język karaimski jako taki), jest jednak trudne lub wręcz niemożliwe, ponieważ nasza wiedza o poszczególnych plemionach zachodnio-turkijskich jest ograniczona.

Wczesny okres średniokaraimski obejmuje czasy, gdy Karaimi zachodni mówili jeszcze jednolitym językiem, niepodzielonym na dialekty (tj. północny i południowy). Jest to więc okres
Late Middle Western Karaim) trwajacy do końca XVIII w. 
trwajacy od momentu wydzielenia się pierwszej fali migracyjnej Karaimów $z$ terenów wspólnej kohabitacji do czasu zmiany ${ }^{*} \eta>j \sim n$ i początku rozwoju harmonii spółgłoskowej w dialekcie północnokaraimskim.

Późny okres średniokaraimski to okres, gdy podział dialektalny języka zachodniokaraimskiego się utrwalił i zaszły w nim najważniejsze zmiany nie tylko odróżniające od siebie jego północny i południowy dialekt, ale również wyróżniajace jego system fonologiczny na tle innych języków kipczackich. Mowa tu o rozwoju harmonii spółgłoskowej w dialekcie północnym, o dwóch różnych drogach zaniku * $y$ w dialekcie północnozachodnim i południowozachodnim oraz o „mazurzeniu” i zaniku samogłosek ö i ü w dialekcie południowozachodnim. Te dwie ostatnie zmiany językowe miały miejsce w ostatnich dekadach XVIII wieku i były ostatnimi procesami zmieniajacymi zasadniczo zachodniokaraimski system fonologiczny. Jest to więc okres trwający mniej więcej od drugiej połowy wieku XVII do końca XVIII.

Dwa ostatnie okresy można traktować razem jako okres średniozachodniokaraimski.

W okresie nowokaraimskim doszło do dalszych zmian językowych zarówno w dialekcie północnozachodnim, jak i w południowozachodnim. Były to jednak zmiany nie wpływajace zasadniczo na fonologię, nawet jeśli pogłębiały różnice między tymi dwoma dialektami. Co istotne, w tym okresie nasilił się wpływ na język zachodniokaraimski otaczajacych go języków słowiańskich: polskiego, ukraińskiego, rosyjskiego i w niewielkim stopniu białoruskiego.

Trudno jest ustalić datę roczną wyznaczająca początek tego okresu, gdyż zmiany językowe to proces długotrwały. Odpowiednia data posiłkowa byłby w tym miejscu na przykład rok urodzenia Jeszui Josefa Mordkowicza (1802-1884), hazzana w Kukizowie (przed 1822 r.) i w Haliczu (1866-1884), a przede wszystkim kopisty kilkudziesięciu woluminów (głównie modlitewników i przekładów Biblii). W rękopisach $z$ jego warsztatu możemy zaobserwować efekt końcowy zarówno „mazurzenia”, jak również zmiany $\ddot{o}>e$ oraz $\ddot{u}>i$. Inna pomocna data mogła by być data III rozbioru Polski (1795), ponieważ od tego momentu nasilała się izolacja gminy halickiej, co w efekcie doprowadziło do wykształcenia się drobnych różnic między poddialektami łuckim i halickim dialektu zachodniokaraimskiego.

Periodyzacja języka wschodniokaraimskiego wcią̇ czeka na należyte, choćby wstępne opracowanie.

\section{DIORTIUŃC̆IU BUJRUHU TIEŃRINIŃ \\ (Šabbatkiuniuńdia biutiuń Džymat ochusun):}

I-184

SAHYNMA SAHYNHYN ol šabbat kiunniu; aziź tutma any. Alty kiuńliar išliagiń; da kylhyn bar išijni. Da ol jedińči kiuń, šabbat Kiučliu Tieńrija; kylmahyn hieč iš sień, da uvluj da kyzyj kuluj da karavašyj da tuvaryj, da haribij ki kabachlaryjda. Ki alty kiuńliardia jaratty Tieńri ol kiokliarni da ol jerni, ol tieńgiźni da baryn nie ki alarda, da tynčaldy ol jedińči kiuńdia; anyn üčiun, alhyšlady Tieńri ol šabbatkiunniu da aziź ètti any.

$* * *$

Dziś jedynym żywym dialektem języka karaimskiego jest dialekt północnozachodni. Istnieje co najmniej kilka sposobów rozróżniania języków martwych od żywych. Najmniej dyskusyjne wydaje się być kryterium polegające na ocenie, czy dany język jest przekazywany droga naturalna z pokolenia na pokolenie. W Haliczu dialekt południowozachodni przestał być przekazywany młodszym pokoleniom od czasów II wojny światowej. W Łucku natomiast stało się to zapewne nieco wcześniej, a cezura jest w przypadku tej gminy I wojna światowa ${ }^{5}$.

Podobna jest sytuacja na Krymie, gdzie dziś już prawie nie ma użytkowników języka karaimskiego. Zostało zaledwie kilka osób w podeszłym wieku, ale $\mathrm{i}$ one nie zawsze miały możliwość posługiwania się językiem karaimskim w domu. Proces asymilacji nasilił się na przełomie XVIII i XIX wieku, kiedy wpływy rosyjskie na Krym stały się silniejsze. Zakaz nauczania języków narodowych w czasach Związku Radzieckiego przypieczętował także los języka wschodniokaraimskiego. I choć jeszcze niedawno istniał plan rewitalizacji języka poprzez nauczanie języka krymskotatarskiego, to jednak tę inicjatywę należy uznać raczej za co najmniej mało realną.

\section{Dyskusja na temat statusu języka krymskokaraimskiego}

Według akceptowanej w szerokich kręgach teorii praojczyzna Karaimów był Półwysep Kryski, skąd pod koniec średniowiecza ich fale osadnicze ruszyły na tereny I Rzeczpospolitej. W XXI wieku coraz częściej pojawiaja się jednak teorie negujące powyższy przebieg zdarzeń. Według najmniej kontrowersyjnej Karaimi mieli przybyć na Ruś Halicką i Litwę $z$ terenów Złotej Ordy (niestety bez bliższego sprecyzowania geograficznego - Złota Orda była przecież olbrzy-
Zapis dialektu północnozachodniego oparty na ortografii litewskiej $z$ elementami polskiej zastosował w swoich publikacjach Mykolas Firkovičius. Karaj dińliliarniń jalbarmach jergialiari, Vilnius 1998. 


\section{СУББОТНИЕ УТРЕІІІИЕ молитвы \\ להור בקר השמע קוליל}

Преветный! Утром Ты усшшш тлас мой, утром предстого Тебе и падегось. И я к Тебе, ІІрсисчшый, взыгаю, и утром молитва моя всэречает Тебя.
Ацонай, эртэ билен этитки авазымны, эріง билен йараштырмын Сапьа тефилламны да батьармын. Да мэн Camь, эй Алонай, йюбарырмым да эртэ билен тефиллам къаршьцар Сэни.
Tekst w krymskiej odmianie języka karaimskiego zapisany cyrylicą. Subbotnie molitvy po obrâdu krymskich Karaimov, wyd. W. Z. Tiriyaki, Eupatoria 2002. mim organizmem państwowym, obejmującym zreszta również Krym) i już przed ich przybyciem na owe tereny mówili różnymi dialektami (to ostatnie twierdzenie neguja najnowsze badania filologiczne i językoznawcze najstarszych znanych rękopisów). Według tej teorii gminy Karaimów na Krymie zostały założone póżniej, przez Karaimów migrujacych $z$ terenów I Rzeczpospolitej. Konsekwencja takiego ujęcia zdarzeń jest negowanie istnienia języka krymskokaraimskiego jako osobnego dialektu - przez zwolenników tej teorii postrzegany jest on jako sztuczny twór ulepiony na bazie języka zachodniokaraimskiego poprzez "zmieszanie” go $z$ językiem krymskotatarskim.

Teoria ta pozostawia wiele do życzenia jeśli chodzi o jej należyte udokumentowanie - zarówno od strony historycznej, jak i filologicznej. Poza tym w świetle licznych źródeł pisanych w języku wschodniokaraimskim (rękopiśmiennych i drukowanych) negowanie jego istnienia jest pozbawione podstaw. Można i należy prowadzić dyskusję nad procesem powstania zabytków językowych w tym języku, należy również dyskutować o jego relacji do dialektów zachodnich lub do języka Tatarów krymskich, trudno jednak zaprzeczać istnieniu czegoś, co istnieje - nawet jeśli zostałoby udowodnione, że język Karaimów krymskich był językiem sztucznym (wbrew relacji tych, dla których dialekt ten był językiem ojczystym).

Dyskusja nad praojczyzna Karaimów oraz nad pochodzeniem ich języka, nawet jeśli była i wciąż jest czasem skrajnie kontrowersyjna, przyniosła pewne ożywienie $\mathrm{w}$ karaimoznaw-

\section{Przypisy:}

${ }^{1}$ Zygmunt Abrahamowicz, Dzieje Karaimów w Haliczu [Rękopis Zygmunta Abrahamowicza przygotowany do druku przez Stefana Gąsiorowskiego], „Przegląd Orientalistyczny” 2001, nr 198-199, s. 3-16.

2 Por. np. Stefan Gasiorowski, Karaimi w Koronie i na Litwie w XV-XVIII wieku. Kraków - Budapest 2008; Dan Shapira, The Turkic languages and literatures of the East European Karaites, w: Polliack, M. (red.): Karaite Judaism. A guide to its history and literary sources, Leiden - Boston 2003, s. 657-728. Ten ostatni autor w ostatnich latach skłania się do myśli, że osiedlenie się Karaimów na Litwie miało miejsce później, dopiero w XV w.

${ }^{3}$ S. Gąsiorowski, Karaimi..., s. 188.

${ }^{4}$ Ibidem, s. $146-148$

${ }^{5}$ Anna Sulimowicz, list prywatny do autora z dnia 16.10.2014. stwie i wymusiła dostosowanie wcześniejszych teorii do współczesnego poziomu stanu wiedzy. I tak wcześniejszy pogląd głoszący, iż Karaimi sa „spadkobiercami” kultury Chazarów należy dziś już traktować $z$ dystansem.

\section{Systemy pisma užywane przez Karaimów}

W swoich dziejach Karaimi posługiwali się trzema systemami pism: hebrajskim, cyrylickim i łacińskim. Pierwszym używanym przez Karaimów było pismo hebrajskie, które zostało przyjęte wraz z religia. Znaczna część literatury sakralnej, liturgicznej i obrzędowej była tłumaczona $z$ języka hebrajskiego i została zapisana tym pismem. Pozostawało ono w powszechnym użyciu (w druku i piśmie odręcznym) mniej więcej do lat 20. XX wieku, ale już od przełomu XIX i XX wieku było stopniowo wypierane przez alfabety cyrylicki i łaciński. I choć pismem hebrajskim posługiwano się przez wiele stuleci, nigdy jednak nie wytworzyła się norma ortograficzna regulująca jego użycie do zapisu języka karaimskiego w którymkolwiek $z$ dialektów. Utworzyły się jedynie pewne standardy i tendencje ortograficzne, a zapis był w dużej mierze zależny od upodobań poszczególnych autorów. Nawet w pojedynczych rękopisach możemy się spotkać z niekonsekwentna pisownia - choć charakteryzowało to sposób pisania przede wszystkim osób mniej wykształconych i miało miejsce w tekstach prywatnych. Co więcej, zapis pismem hebrajskim różnił się dodatkowo w zależności od tego, czy piszacy wokalizował tekst (a więc czy używał dodatkowych znaków umieszczanych pod literami dla zaznaczenia jaka samogłoska występuje w danym miejscu), czy też pisał bez wokalizacji. Najbardziej różnorodny był zapis samogłosek, mniejszą nieregularnościa charakteryzował się zaś zapis spółgłosek.

W piśmie odręcznym Karaimi używali charakterystycznej dla nich kursywy i tzw. półkursywy. Kształty niektórych liter używanych przez Karaimów zachodnich znacznie się różniły od tych używanych na Krymie.

Posługiwanie się pismem cyrylickim stało się powszechne w chwili, gdy zaczęto publikować literaturę świecką na terenie Imperium Rosyjskiego. Pierwsza publikacją w języku karaimskim zapisana $\mathrm{w}$ tym alfabecie był wydany w 1904 r. w Kijowie tom Irłar (Ирларъ, Pieśni) Szymona A. Kobeckiego (1865?-1933?). Użycie rosyjskiej grażdanki, $z$ pewnymi modyfikacjami, umożliwiło oddanie wszystkich cech fo- 
netycznych języka karaimskiego, co w przypadku pisma hebrajskiego było niemożliwe. Przyczyniło się to zreszta do wielkiej popularności poety - lektura tekstu cyrylickiego była bowiem bardziej przystępna. Cyrylicy używano w Rosji, na Krymie oraz po drugiej wojnie światowej również na Litwie aż do rozpadu Związku Radzieckiego.

Pismo łacińskie używane do zapisu karaimskiego rozpowszechniło się na dobre w Polsce w okresie międzywojennym. Ortografia była oparta na pisowni polskiej (używano znaków $c h, c z, \dot{c}, d z, d \dot{z}, t, \dot{n}, s z, s, w, y, \dot{z}, \dot{z})$ uzupełnionej o znaki specjalne $(\ddot{o}, \ddot{u}, t, d)$. Była stosunkowo regularna, choć zauważyć możemy kilka nieregularności. Na przykład dla zapisu spółgłoski $k$ przed samogłoska - $e$ - (w takiej pozycji ulegała ona zmiękczeniu - podobnie jak w języku polskim) stosowano trzy rozwiąania. Zmiękczenie zaznaczano albo apostrofem (np. k'ez 'oko' w dialekcie południowozachodnim), albo litera $i$ (tak, jak w ortografii polskiej; np. kiez 'oko'), albo stosujacc zapis przypominajacy ortografię turecka, a więc w ogóle nie zaznaczajac zmiękczenia (czyli pisano kez 'oko').

Po uzyskaniu przez Litwę niepodległości zmodyfikowano ten alfabet i częściowo oparto go na litewskiej grafii (zob. litery $\check{c}, \dot{e}, \check{s}, v, z$ ) $z$ elementami polskiej pisowni (zob. litery ch, ń, ś, ź), oraz wprowadzono znak l'. Oprócz tego systemu funkcjonuje niekiedy, choć rzadko, zapis oparty wyłącznie na polskiej grafii, co oznacza, że nadal nie ma jednego spójnego systemu ortograficznego opracowanego dla dialektu północnego.

Michał Németh

\section{Bibliografia}

Éva Ágnes Csató, The Karaim language in $\mathrm{Ha}$ lych, w: Novochatko, L., Fedoruk, O., Beregovśkyj, O. (red.): Karajimy Galyča: istorija ta kultura. Lviv-Galyč 2002, s. 135-139.

Henryk Jankowski, The question of the existence of the Crimean Karaim and its relation to western Karaim, w: Bairašauskaitè, T., Kobeckaitè, H., Miškinienè, G. (red.): Orientas Lietuvos Didžiosios Kunigaikštijos visuomenès tradicijoje: totoriai ir karaimai (= Straipsniu rinkinys, parengtas pranešimu, skaitytu tarptautineje mokslo konferencijoje „610 osios totoriu ir karaimu isikikurimo Lietuvos Didžiojoje Kunigaikštijoje metinès" $2007 \mathrm{~m}$. rugsèjo 13-15 d. Vilniaus universitete, pagrindu), Vilnius 2008, s. $162-168$.
Jankowski, Henryk, Crimean Turkish Karaim and the old north-western Turkic tradition of the Karaites, „Acta Orientalia Academiae Scientiarum Hungaricae" 2015, t. 68/2, s. 199-214.

Małgorzata Machcińska, Lieszon hak-Kodiesz. Zagadnienia pisowni i wymowy hebrajszczyzny Karaimów polsko-litewskich (= Prace Karaimoznawcze 3), Poznań 2015.

Michał Németh, Unknown Lutsk Karaim Letters in Hebrew Script (19th - 20th Centuries). A Critical Edition (= Studia Turcologica Cracoviensia 12). Kraków 2011.

Michał Németh, A historical phonology of Western Karaim. Alveolars and front labials in the south-western dialect, „Studia Linguistica Universitatis Iagellonicae Cracoviensis" 2014, t. $131 / 3$, s. 247-267.

Michał Németh, 2014b. A historical phonology of Western Karaim. The evolution of consonant harmony in the north-western dialect. „Studia Linguistica Universitatis Iagellonicae Cracoviensis" 2014, t. 131/4, s. 353-369.

Michał Németh, A historical phonology of Western Karaim. The process of diversification into dialects [złożone do druku w: Studia Linguistica Universitatis Iagellonicae Cracoviensis 2015, t. 132].

Zsuzsanna Olach, A Halich Karaim translation of Hebrew biblical texts (= Turcologica 98), Wiesbaden 2013.

Zsuzsanna Olach, Debated issues in Karaim Hebrew orthography, „Acta Orientalia Academiae Scientiarum Hungaricae", 2015, t. 68, s. 183-197.

Dan Shapira, The Turkic languages and literatures of the East European Karaites, w: Polliack, M. (red.): Karaite Judaism. A guide to its history and literary sources. Leiden - Boston 2003, s. 657-728.

Dan Shapira, The Karaim translation of the Book of Nehemia copied in the 17th century's Crimea and printed in 1840/1841 at Gözleve, on the copyist of the manuscript, and some related issues, „Karaite Archives” 2013, t. 1, s. 133-198.

Ananiasz Zajaczkowski, Karaims in Poland: history, language, folklore, science. Warszawa Paris 1961.
Przykład zapisu dialektu południowozachodniego w ortografii polskiej. Początek bajki Eljahunun ucuru, pierwszej publikacji Aleksandra Mardkowicza, wydanej w Łucku w roku 1930.
Bir kart jomak ajtad, ki jirak jerde tiri edi ez anasyba bir erułan atyba Elijahu. Atasy anyn kacanes edi chodzà bezirgien ol saharda Efeste, kajsy jatad tengizkatyn ta kajda awałhy zamanłarda tabułuredłer Karajłar. 